\title{
Ołtarze z cudownymi wizerunkami w twórczości braci Polejowskich ${ }^{1}$
}

K

ult cudownych wizerunków (głównie maryjnych) wywarł znaczący wpływ na artystyczne przekształcenia wnętrz sakralnych w XVIII stuleciu². W województwie ruskim te działania przyczyniły się do powstania najlepszych realizacji artystycznych w osiemnastowiecznej Rzeczypospolitej. Większość z nich łączy się bezpośrednio lub pośrednio z braćmi Piotrem i Maciejem Polejowskimi. Warto zatem podjąć próbę analizy wypracowanych przez nich rozwiązań kompozycyjnych na wybranych przykładach

Twórczość Piotra Polejowskiego wnikliwie przeanalizowali Piotr Krasny i Jakub $\mathrm{Sito}^{3}$, a następnie sam Krasny omówił zjawisko kompleksowych wystrojów wnętrz

1 Niniejszy tekst powstał w ramach badań finansowanych z grantu Narodowego Centrum Nauki nr UMO2014/13/N/HS2/02923 pt. Lwowskie rodziny artystyczne drugiej połowy XVIII stulecia oraz pracy nad rozprawą doktorską na temat działalności artystycznej rodziny Polejowskich, przygotowywanej pod kierunkiem dra hab. Andrzeja Betleja w Instytucie Historii Sztuki UJ, któremu bardzo dziękuję za wszystkie uwagi i wskazówki.

2 Podstawowe opracowanie na ten temat, zobacz: BARANOWSKI 2003.

3 KRASNY/SITO 2003. 


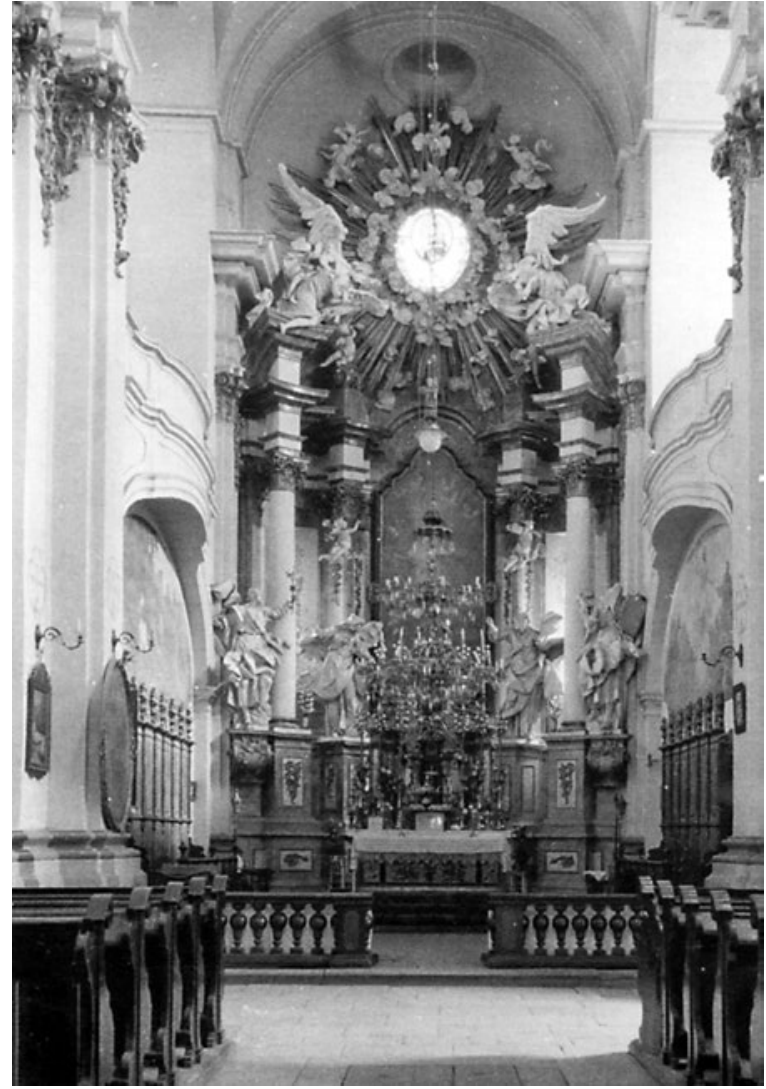

B. Meretyn (projekt), J. G. Pinsel

(dekoracja rzeźbiarska), Horodenka, kościół Misjonarzy, ołtarz główny, przed 1761, fot. Zbigniew Hornung, przed 1939

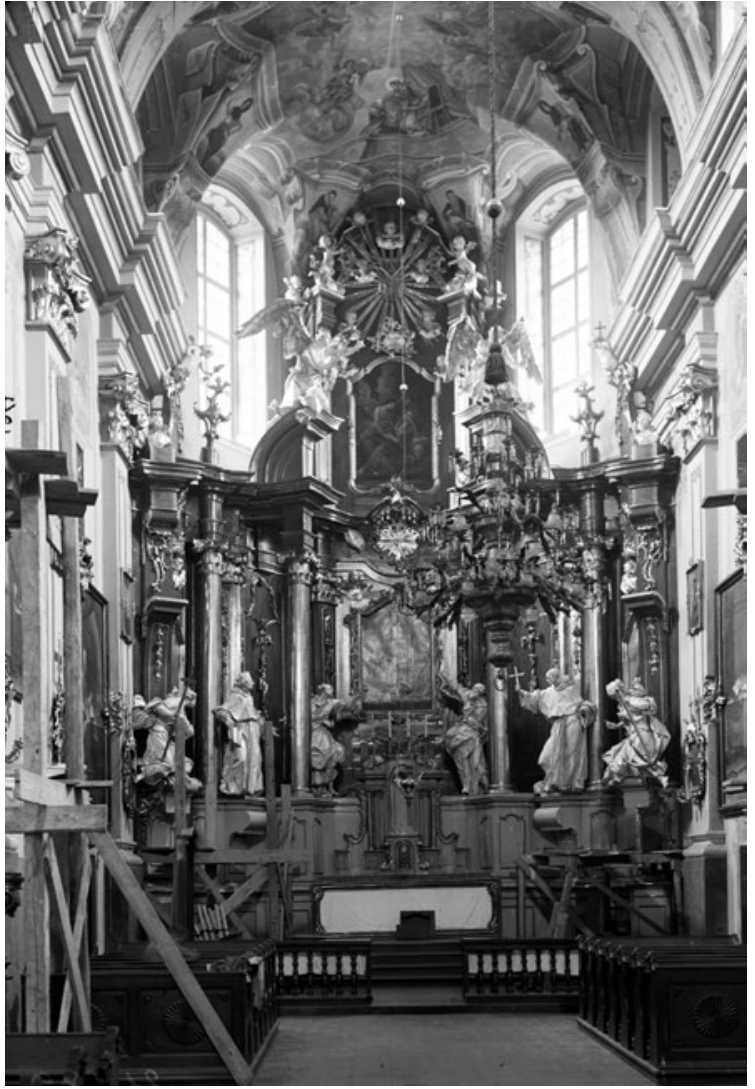

P. Polejowski (projekt i dekoracja rzeźbiarska), M. Olaszkiewicz (wyk. nastawy),

Przemyśl, kościół Franciszkanów, ołtarz główny, 1761-1765, fot. Adam Bochnak, 1927

w lwowskim środowisku artystycznym ${ }^{4}$. Działalność Macieja Polejowskiego nie była dotąd rozpatrywana całościowo ${ }^{5}$.

Znaczącą rolę w kształtowaniu osobowości twórczej obu braci odegrała nauka w warsztacie Bernarda i Jana Jerzego Pinsla, deklarowana przez Macieja w słynnym liście do bazylianów z 1783 roku6 Jak wykazali Krasny i Sito główną inspiracją dla projektów małej architektury Piotra był meretynowski ołtarz główny w Horodence,

KRASNY 2005a.

Pojedyncze zagadnienia podejmowali dotychczas: KOWALCZYK 1959; KOWALCZYK 1970; BETLEJ 1995; BRZEZINA 2004; BETLEJ 2006; DWORZAK 2013; DWORZAK 2016. Próbę szerszej analizy podjął KRASNY 2005a oraz DWORZAK 2014.

6 DUTKIEWICZ 1935, s. 144; KOWALCZYK 1970, s. 192; GĘBAROWICZ 1986, s. 17; BETLEJ 2003, s. 373-380; DWORZAK 2013, s. 101-114. 
wprowadzający awangardowe rozwiązania kompozycyjne ${ }^{7}$. Także Maciej Polejowski inspirował się w swych projektach dziełem z Horodenki, przy którym pracował jako czeladnik. Obaj bracia wyciągnęli jednak odmienne wnioski z tej realizacji, wykorzystując różne rozwiązania i twórczo je rozwijając.

Kontynuacją sposobu postrzegania architektury przez Meretyna był ołtarz główny z kościoła oo. Franciszkanów przemyskich, na który Piotr Polejowski podpisał kontrakt w 1761 roku. Zlecenie to było kulminacyjnym momentem fabryki kościoła, prowadzonej od 1754 roku w związku z planami koronacji wizerunku Matki Boskiej Niepokalanej. Warto podkreślić, że zamówienie ołtarza nastąpiło bezpośrednio po ogłoszonym w grudniu 1760 roku dekrecie biskupa przemyskiego Michała Wodzickiego, potwierdzającego cudowność obrazu. Planowana struktura miała więc odpowiednio wyeksponować znaczenie wizerunku. Polejowski rozbudował silnie wertykalny schemat horodeńskiego ołtarza o aneksy otwarte na ściany prezbiterium, uzyskując tym samym zamówiony przez franciszkanów ołtarz wielki, w którym powinno być ołtarzy trzy 9 .

Krasny i Sito podkreślali, że zabieg ten świadczył o wysokich umiejętnościach Polejowskiego, który uzyskał jednolitą kompozycję struktury poprzez umiejętne rozmieszczenie w niej kolumn i dekoracji figuralnej ${ }^{10}$. Można jednak zauważyć, że taki zabieg spowodował także mocne oddzielenie dwóch kondygnacji nastawy. Rozbudowana, eliptyczna w rzucie struktura pierwszej kondygnacji została skontrastowana z mocno wydłużonym zwieńczeniem części środkowej. Jej odseparowanie od pozostałej części ołtarza dodatkowo podkreśla światło padające z flankujących je okien. Próbą powiązania obu stref ołtarza było zakończenie zewnętrznych krańców nastawy „falami” z rocaille’em i umieszczenie w partii belkowania ścian prezbiterium puttów, a poniżej dosyć rachitycznych, mocno wydłużonych wazonów rocaille’owych w prześwitach okien. Efekt jedności kompozycyjnej widoczny jest, gdy się patrzy na ołtarz z linii prezbiterium, kiedy wzrok zwrócony w górę natrafia na spiętrzone plany nastawy.

Część środkowa ołtarza przemyskiego podporządkowana jest cudownemu obrazowi umieszczonemu w rokokowej ramie, ku której zwracają się postacie śś. Piotra i Pawła, św. Franciszka i bł. Jana Dunsa Szkota oraz personifikacje Wiary i Nadziei. Ruch dośrodkowy głównej części nastawy został podkreślony poprzez ukośne ustawienie rzeźb, jak również poprzez dającą się zauważyć gradację dynamizmu 
postaci. Zewnętrzne personifikacje ukazane w największym skrócie, niemal w skłonie (dobrze znanym ze zwieńczeń ołtarzy lwowskich, choćby katedralnego), stanowią pierwszą kulisę kierującą wzrok ku głównemu przedstawieniu. Ruch diagonalny podkreślono tutaj poprzez skośne udrapowanie szat i „rozwianie” rękawów postaci. Druga para rzeźb jest wyraźnie mniej dynamiczna. Polejowski ograniczył gwałtowność i nagromadzenie draperii, na rzecz szerokich, ostro łamanych płaszczyzn, osiągając efekt monumentalności. Postacie śś. Piotra i Pawła, dynamicznie wygięte, owinięte połami gniecionego materiału, pełnią de facto funkcję "trzymaczy”, „zlewając się" z oddali z ramą cudownego wizerunku. Szkoda, że Polejowski nie zdecydował się na nieznacznie podniesienie tej pary rzeźb, mocniej eksponując, i tak dający się zauważyć, efekt wznoszącej kompozycji.

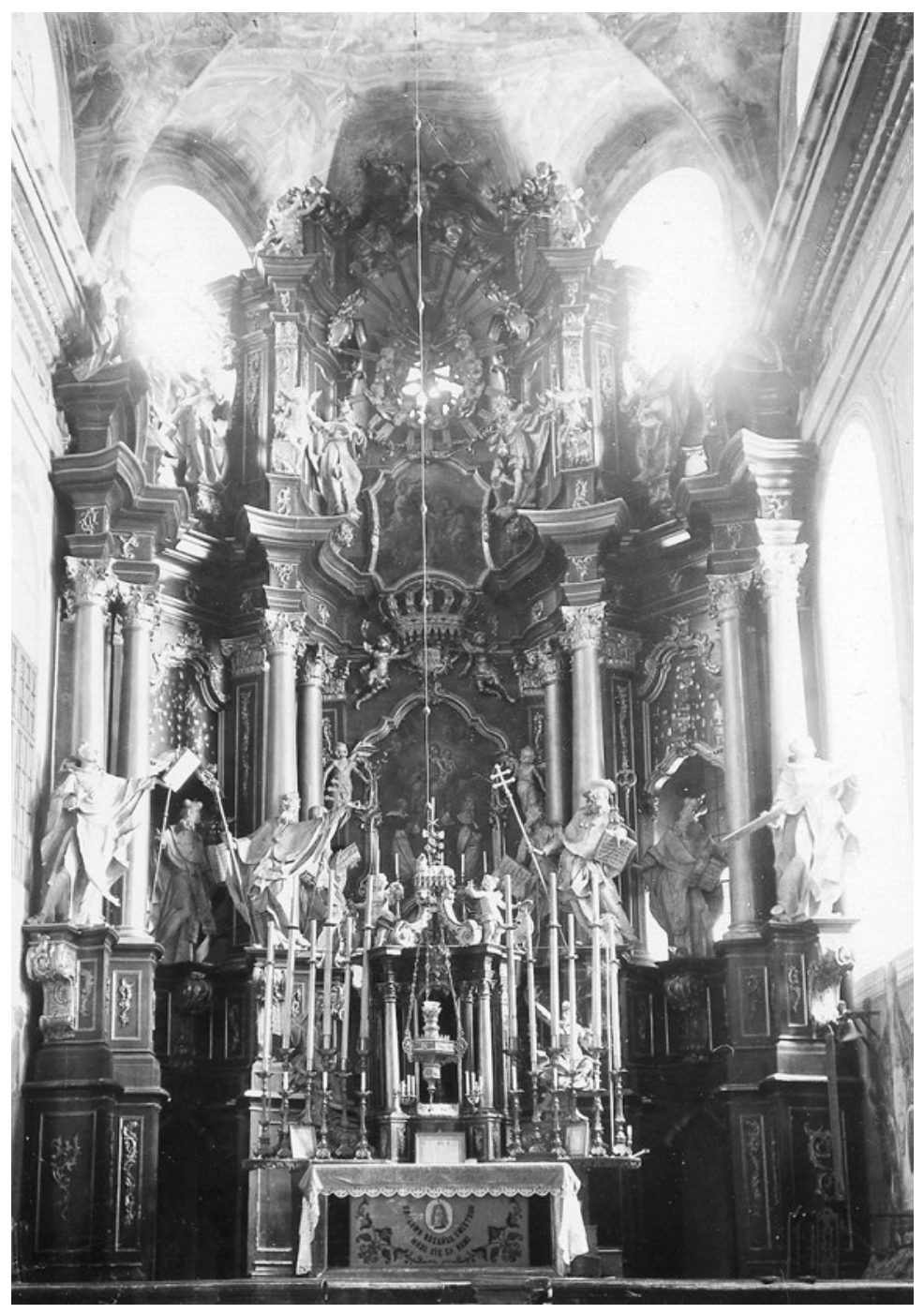

P. Polejowski (atryb.), Podkamień, kościół Dominikanów, ołtarz główny, 1764 - ok. 1766 , fot. przed 1939 
Przyjmując atrybucję Krasnego ${ }^{11}$, można stwierdzić, że kolejnym etapem ewolucji pomysłu z Przemyśla była nastawa w kościele oo. Dominikanów w Podkamieniu, realizowana od 1764 roku, równocześnie z początkiem modernizacji katedry łacińskiej we Lwowie. Inicjatorem zlecenia był Mikołaj Bazyli Potocki. W tym wypadku schemat nastawy z Horodenki został niemal dosłownie otwarty na szerokość prezbiterium. Zewnętrzne kolumny z impostami i ćwierćkolistymi przyczółkami, $\mathrm{z}$ adorującymi aniołami (które w Horodence domykają przestrzeń ołtarza, zagarniając ją ku centrum) zostały w Podkamieniu oparte o ściany prezbiterium, jednocześnie eksponując oś główną z cudownym wizerunkiem Matki Boskiej.

Polejowski uzyskał niejako „ołtarz w ołtarzu”, tworząc kilka planów w samej nastawie i mocne kontrasty światłocieniowe potęgujące plastykę. Jak się wydaje wyciągnął wnioski z realizacji przemyskiej i ołtarz dominikański jest bardziej zintegrowany. Podniesienie zewnętrznych osi struktury, poprzez przyczółki z rzeźbami, spowodowało płynne przejście pomiędzy kondygnacjami i silne podkreślenie głównej osi retabulum z cudownym obrazem.

Uzupełnieniem kompozycji jest dekoracja figuralna ośmiu ponadnaturalnych postaci doktorów kościoła i świętych dominikańskich w dolnej kondygnacji i sześć figur w zwieńczeniu, w otoczeniu bogatej dekoracji ornamentalnej. Cofnięte partie ołtarza zaaranżowane w formie wnęk z rzeźbami doświetlają, podobnie jak w Horodence, ukryte za strukturą okna, wydobywając z mroku postaci śś. Jana Chryzostoma i Bazylego.

Osobną kwestię stanowi atrybucja rzeźb, które ewidentnie nie są w żaden sposób powiązane z Fabianem Fesingerem, jak chciał Hornung ${ }^{12}$, czy też warsztatem Sebastiana Fesingera, jak twierdził Krasny ${ }^{13}$. Charakterystyczne mocne wychylenie sylwetek postaci, szerokie, zaostrzone na załamaniach, sztywne i „metaliczne” fałdy szat wskazują na autorstwo Antoniego Osińskiego. Szereg analogii ujawnia porównanie figur podkamienieckich z jego realizacjami w Zbarażu i Leżajsku.

Maciej Polejowski zaczerpnął z retabulum w Horodence przede wszystkim elementy dekoracyjne i szczegółowe rozwiązania. W grudniu 1773 roku Polejowski wyraził negatywną opinię o dotychczasowym ołtarzu głównym w kościele oo. Bernardynów w Zasławiu na Wołyniu, a zakonnicy zdecydowali powierzyć mu wykonanie nowej ${ }^{14}$.

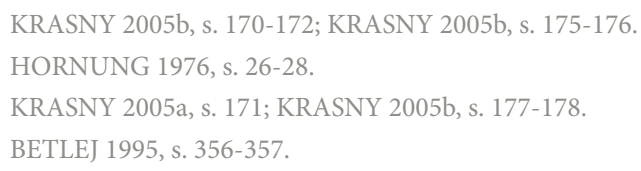


Warto w tym miejscu podkreślić, że zakrojona na szeroką skalę modernizacja kościoła zasławskiego zainicjowana przez Pawła Karola Sanguszkę w końcu lat 20. XVIII wieku była związana z odnalezieniem w sanktuarium w Rzeszowie cudownego wizerunku Matki Boskiej Zasławskiej, uważanej wówczas za bezpowrotnie utraconą (spaloną wraz z kościołem przez wojska Chmielnickiego) ${ }^{15}$. Ostatnim elementem odnowy sanktuarium było właśnie wykonanie przez Polejowskiego części

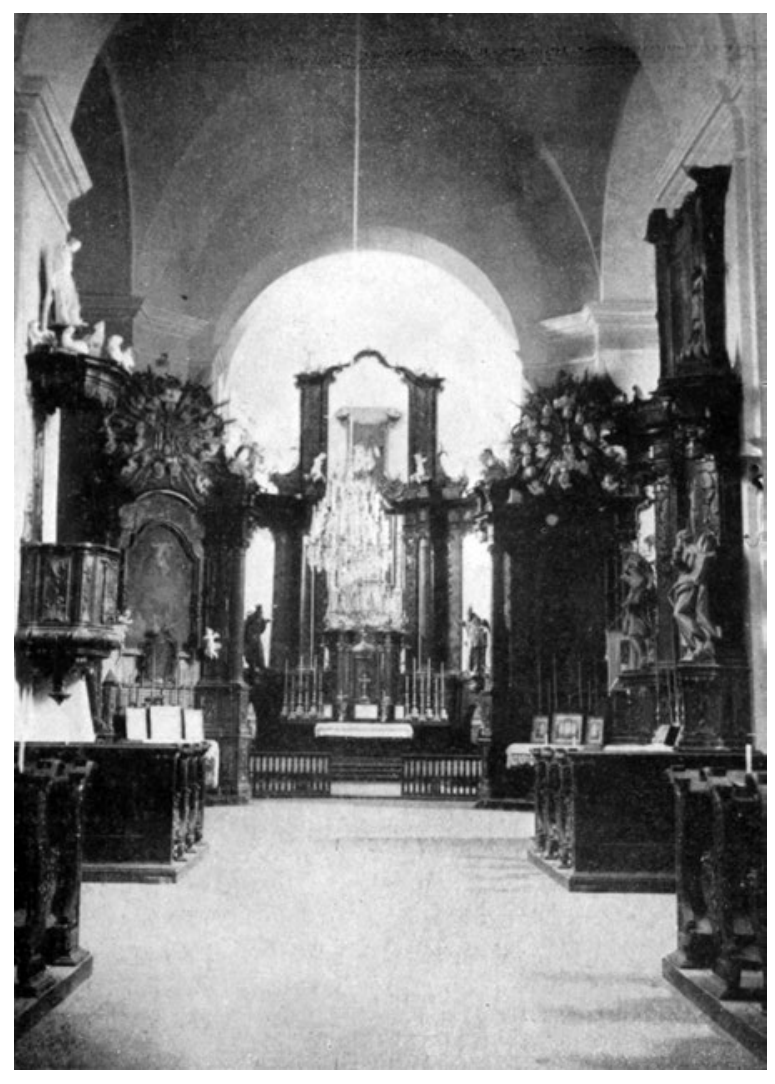

M. Polejowski,

Zasław, kościół Bernardynów, ottarz gł. wyk. 1774, fot. lata 20. XX w.

nowego wyposażenia i uroczyste przeniesienie do niego cudownej ikony. Artysta wykorzystał w Zasławiu schemat ołtarza wypracowany w kolegiacie sandomierskiej, co nie może dziwić wobec ukończenia tego dzieła niecałe dwa miesiące przed przybyciem do Zasławia. Proste formy architektoniczne wnętrza zostały zdominowane przez struktury ołtarzy bocznych, stanowiących kulisy i kierujących wzrok widza ku cudownemu wizerunkowi Matki Boskiej Zasławskiej. Polejowski umiejętnie właczył w kompozycję ołtarza głównego, zastane w światyni struktury przytęczowych ołtarzy p.w. św. Jana Nepomucena i św. Wincentego (określanego także jako ołtarz 
Przemienienia Pańskiego $)^{16}$. Tworzą one kulisy i wkraczają w przestrzeń arkady tęczowej za pomocą kolumn na ukośnie dostawionych cokołach. W ten sposób zwężono przejście do prezbiterium, kierując wzrok widza ku dwuplanowej, ażurowej strukturze ołtarza głównego.

Pierwszy plan stanowiła założona na wklęsłym, eliptycznym rzucie przegroda podzielona kolumnami i pilastrami. Otwierała się na znacznej wielkości prześwity, w części centralnej zamknięta była zwieńczeniem utworzonym z pary pilastrów $\mathrm{z}$ wolutami spiętymi od góry rocaille’owym grzebieniem. W zewnętrznych prześwitach ustawiono rzeźby zakonników bernardyńskich, na głównej osi zaś rozbudowane tabernakulum, zza którego wyłaniał się przyścienny ołtarz z cudownym wizerunkiem. Górną kondygnację bramki zdobią znane z Horodenki umieszczone na skrajach postacie świętych na racaille’owych falach i liczne putta. Poniżej podtrzymują one kapitele nieistniejących kolumn nad prześwitami. To bodaj ulubiony meretynowski motyw Macieja Polejowskiego, zastosowany również w Sandomierzu, jednak $\mathrm{w}$ innej redakcji, niepowtarzający dosłownie pierwowzoru.

16 Ich wykonawcą był Jan Pusz z Annopola, który zmarł nie wykończywszy ołtarzy, a w 1765 roku dekorację rzeźbiarską wykonał do tych dwóch nastaw lwowski rzeźbiarz Józef Sztyl, BETLEJ 1995, s. 355.

M. Polejowski,

Zasław, kościół Bernardynów, ołtarz główny, wyk. 1774, fragment części centralnej, fot. 1913,

wg. Marcjan Tokarzewski,

Z kronik zakonnych kościoła i klasztoru oo. Bernardynów w Zasławiu na Wołyniu,

Warszawa 1913

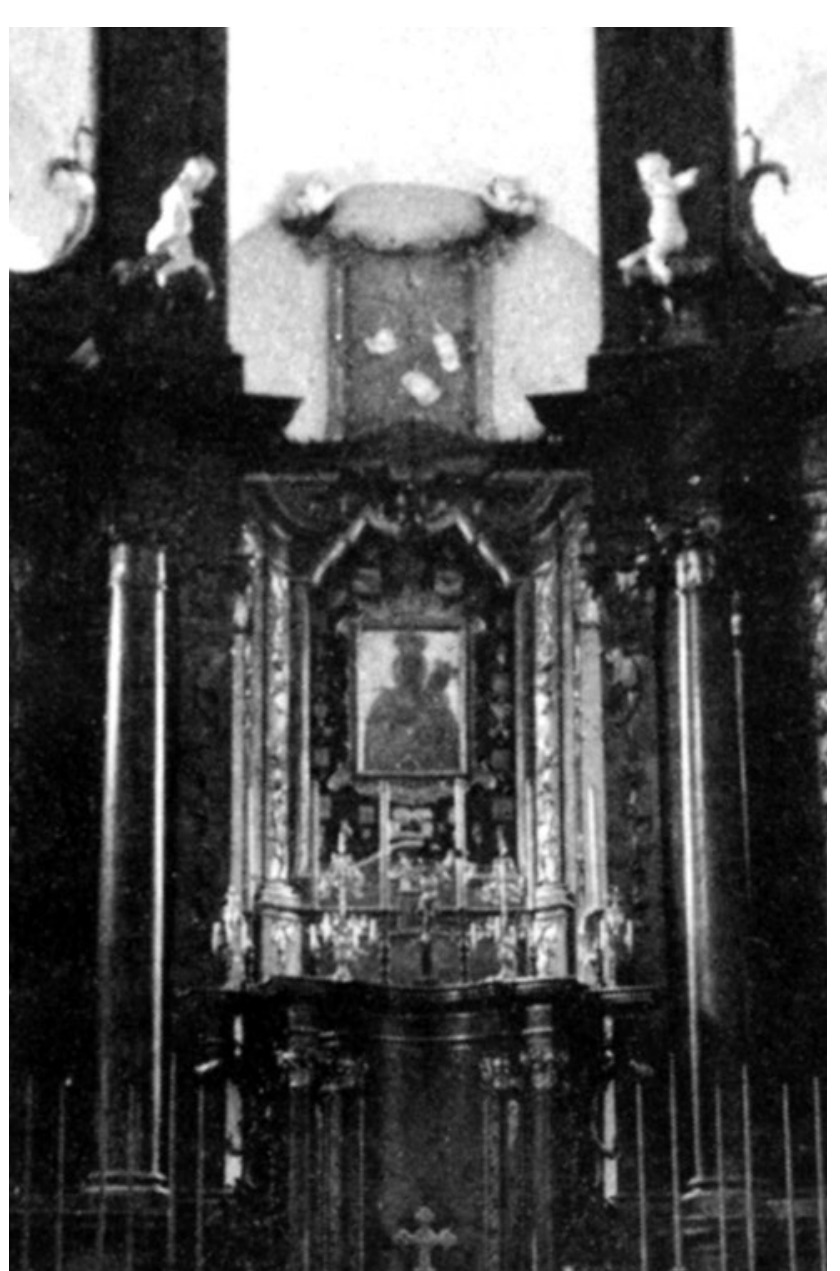


Dwa interesujące zabiegi optyczne wykorzystane przez rzeźbiarza w Zasławiu decydują o atrakcyjności i znaczeniu tej realizacji. Przede wszystkim przyścienna część ołtarza została zaprojektowana na rzucie otwartej elipsy, ze zwielokrotnionymi pilastrami zwieńczonymi falującymi odcinkami gzymsu. Dokładnie powtórzono układ środkowej części ołtarza z Sandomierza. A cudowny obraz umieszczono $\mathrm{w}$ dodatkowej wnęce. Zwieńczenie przegrody szeroko rozstawionymi wiązkami pilastrów, a w ich tle górnej kondygnacji przyściennego ołtarza, pozwoliło na iluzję zlania się obu planów w jedną całość widzianą z końca nawy. Widoczna jest także mocna tendencja Polejowskiego do budowania kompozycji centralnej, poprzez umieszczenie na głównej osi rozbudowanego tabernakulum, które z oddali pełniło funkcję iluzjonistycznej „podstawy” dla cudownego obrazu. Andrzej Betlej

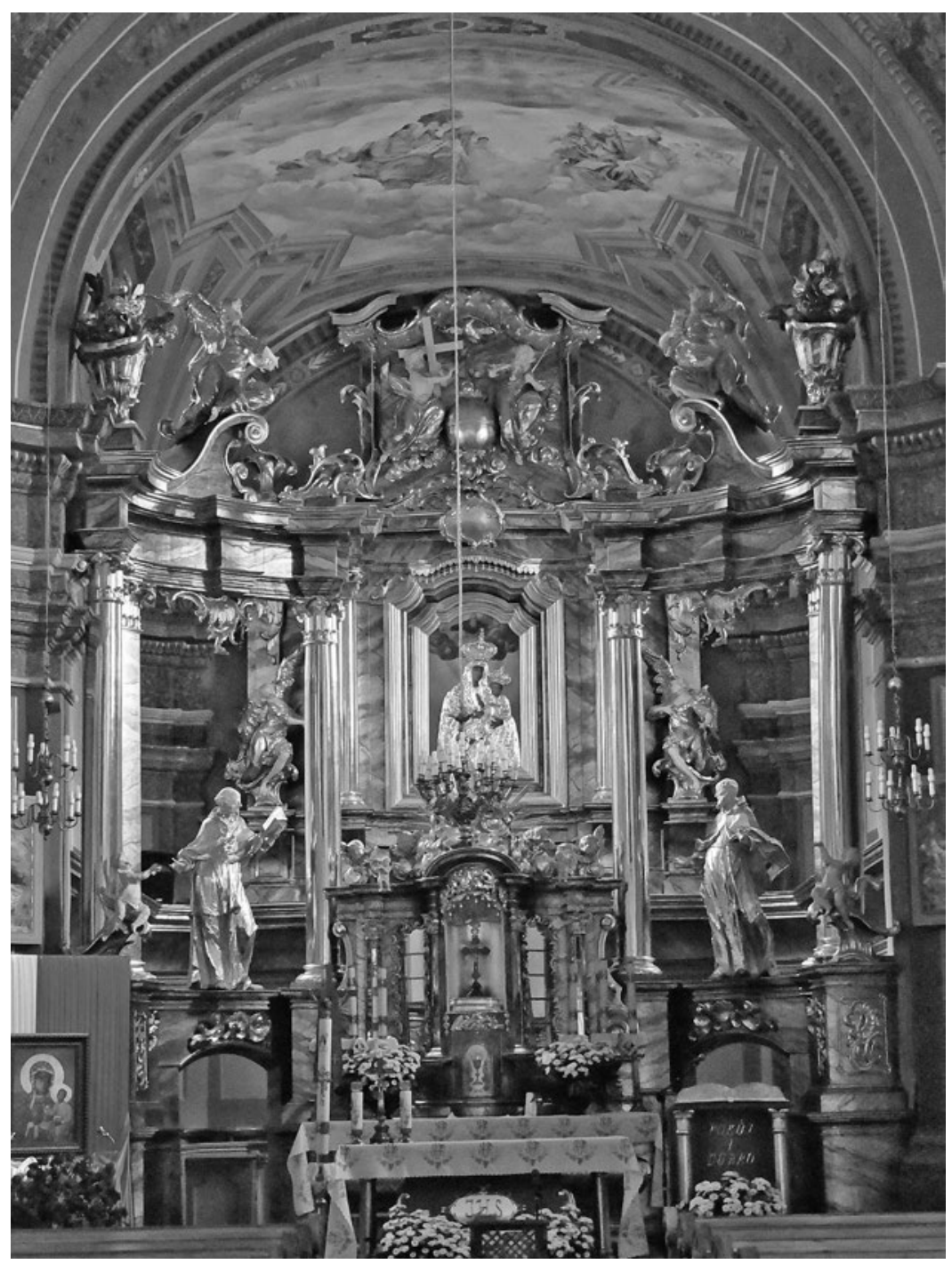

M. Polejowski,

Opatów, kościół Bernardynów, ołtarz główny, 1784?, fot. Agata Dworzak, 2015 
wskazywał na inspiracje Macieja projektami Johanna Michaela Leuchtego wydawanymi przez Martina Engelbrechta ${ }^{17}$. Piotr Krasny natomiast widział odwołanie się w nastawie zasławskiej do ołtarza w kościele Santa Maria de Mercede w Wiedniu ${ }^{18}$. Jak się wydaje bezpośrednich inspiracji należy jednak szukać bliżej, we Lwowie, w ołtarzu głównym u bernardynów wprowadzającym dwuplanowe, ażurowe struktury do sztuki lwowskiej.

Dosyć wiernym powtórzeniem schematu zasławskiego jest ołtarz główny w kościele tego zakonu w Opatowie. Jerzy Kowalczyk datował ołtarz opatowski na lata 1770-1775, wskazując na jego dwufazowość ${ }^{19}$, natomiast Betlej na bazie zapisów w kronice klasztornej przesunął czas powstania na lata 1765-1766 i uznał jego homogenicznośćc ${ }^{20}$. Katarzyna Brzezina, przyjmując datowanie Betleja, ponownie rozdzieliła powstanie struktury i dekoracji rzeźbiarskiej, wskazując jednocześnie na domniemany udział w wykonaniu nastawy warsztatu Antoniego Gegenbaura ${ }^{21}$.

Należy jednak odrzucić powracające supozycje o dwufazowości struktury. Sposób jednolitego zakomponowania architektury i dekoracji ołtarza a także uzupełnianie się planów nie pozostawiają wątpliwości, że dzieło zostało wykonane jako całość. Dodatkowo należy zwrócić uwagę, że przednia przegroda, według Brzeziny wykonana przez rzeźbiarzy z Krakowa, niemal dokładnie powtarza rozwiązanie z Zasławia. Polejowski przesunął tylko ustawienie pilastrów, które w Zasławiu flankowały centralny prześwit, w Opatowie zaś zostały odstawione bardziej ku zewnętrznym kolumnom (być może, aby ukryć źródła światła z bocznych okien). Analogiczne jest zastosowanie rocaille’owych zwisów pod belkowaniem, w Opatowie brak tylko puttów podtrzymujących kapitele, co wynika z przesunięcia pilastrów. Rzeźbiarz nie zdecydował się na umieszczenie tego motywu pod pozorowanym wyłamaniem belkowania, bowiem wypadało ono na linii ustawionej figury i mogło zacierać klarowność kompozycji. Podobnie jak w Zasławu zakomponowano także tabernakulum jako „podstawę” pod obraz maryjny, który obudowano przyściennym retabulum, o formach znanych z Sandomierza i Zasławia.

Pozostaje zatem kwestia możliwego czasu powstania struktury. Wyabstrahowanie dzieła opatowskiego z całej twórczości Macieja Polejowskiego doprowadziło do pewnego paradoksu. Przyjmując datowanie powiązane z konsekracją przebudowanej świątyni w 1765 roku, włączamy Opatów do najwcześniejszych potwierdzonych

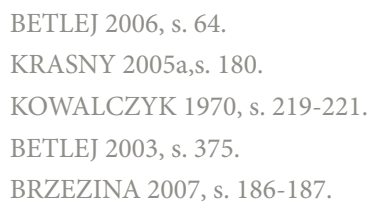



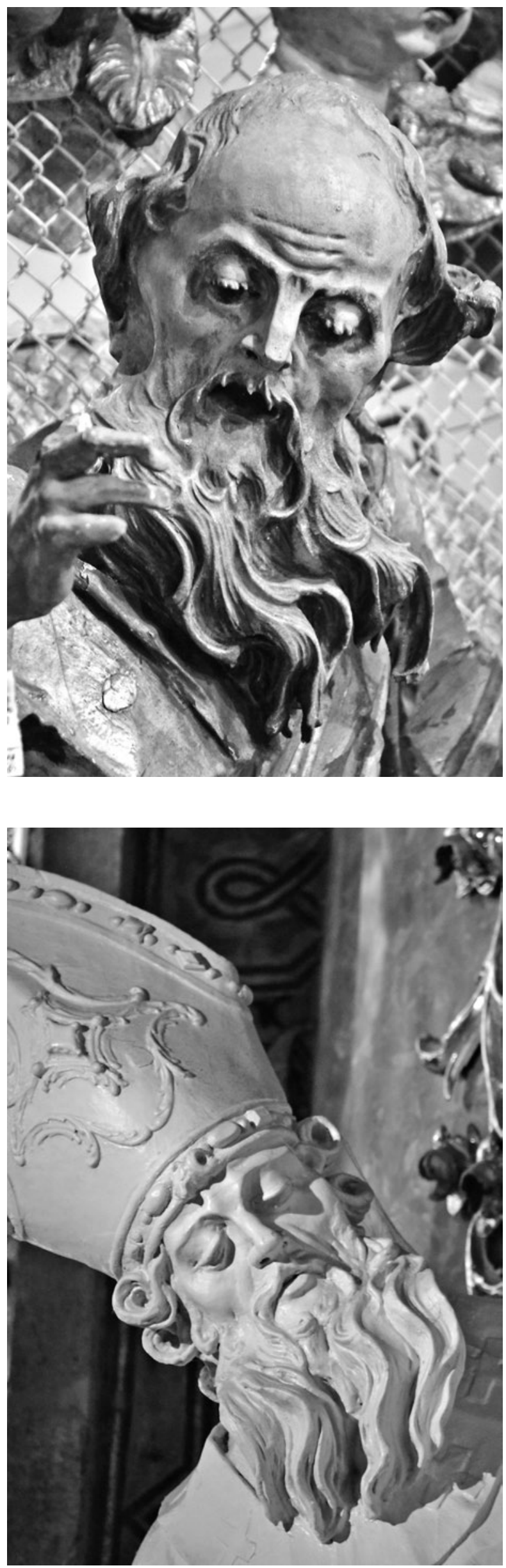

M. Polejowski, Nawaria,

kościół parafialny, figura

Boga Ojca ze zwieńczenia

z ołtarza głównego,

wyk. ok 1765-1766, ob. Olesko,

magazyn rzeźby

Lwowskiej Galerii Sztuki

im. Borysa Woźnickiego,

fot. A. Dworzak, 2016

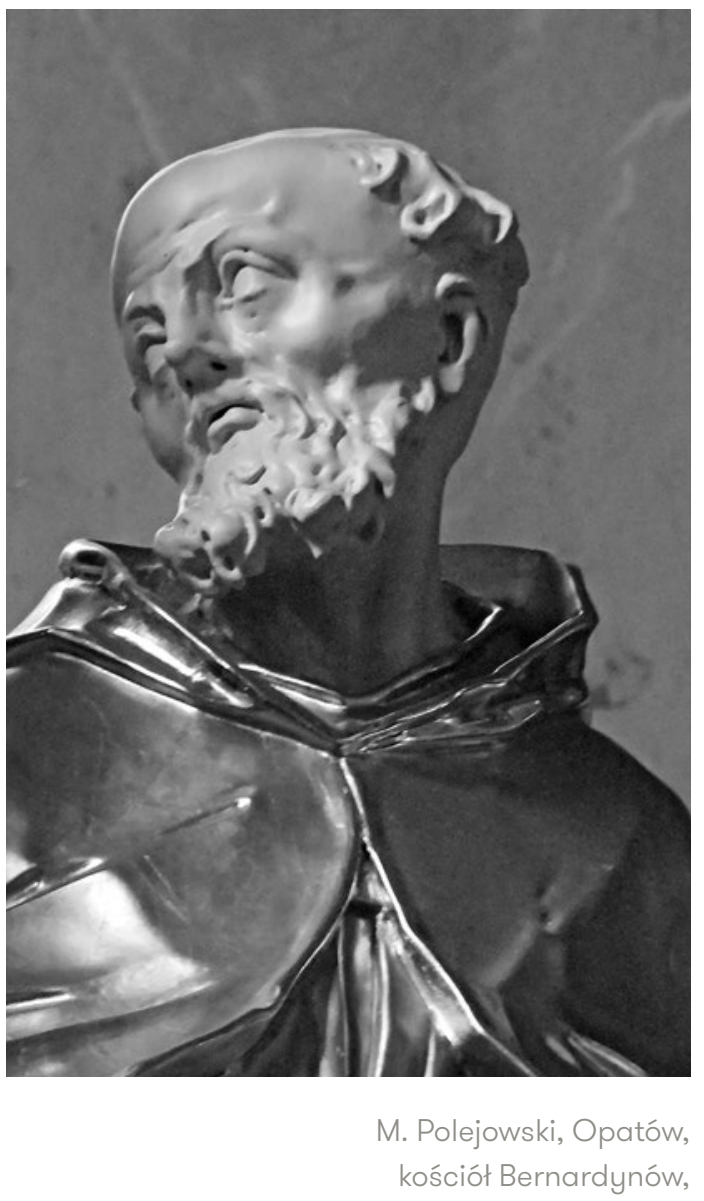

figura św. Bonawentury

w ołtarzu głównym, wyk. 1784?,

fot. Agata Dworzak, 2014

M. Polejowski, Lwów,

katedra łacińska,

figura św. Augustyna w ottarzu

głównym, wyk. 1765-1770,

fot. Agata Dworzak, 2015 

$215 \mid \begin{aligned} & \text { TECHNE } \\ & \text { TERIA N N N HA }\end{aligned}$

M. Polejowski, Włodawa, kościół Paulinów, rzeźba w ołtarzu głównym,

wyk. pom. 1784-1785, fot. Agata Dworzak, 2013
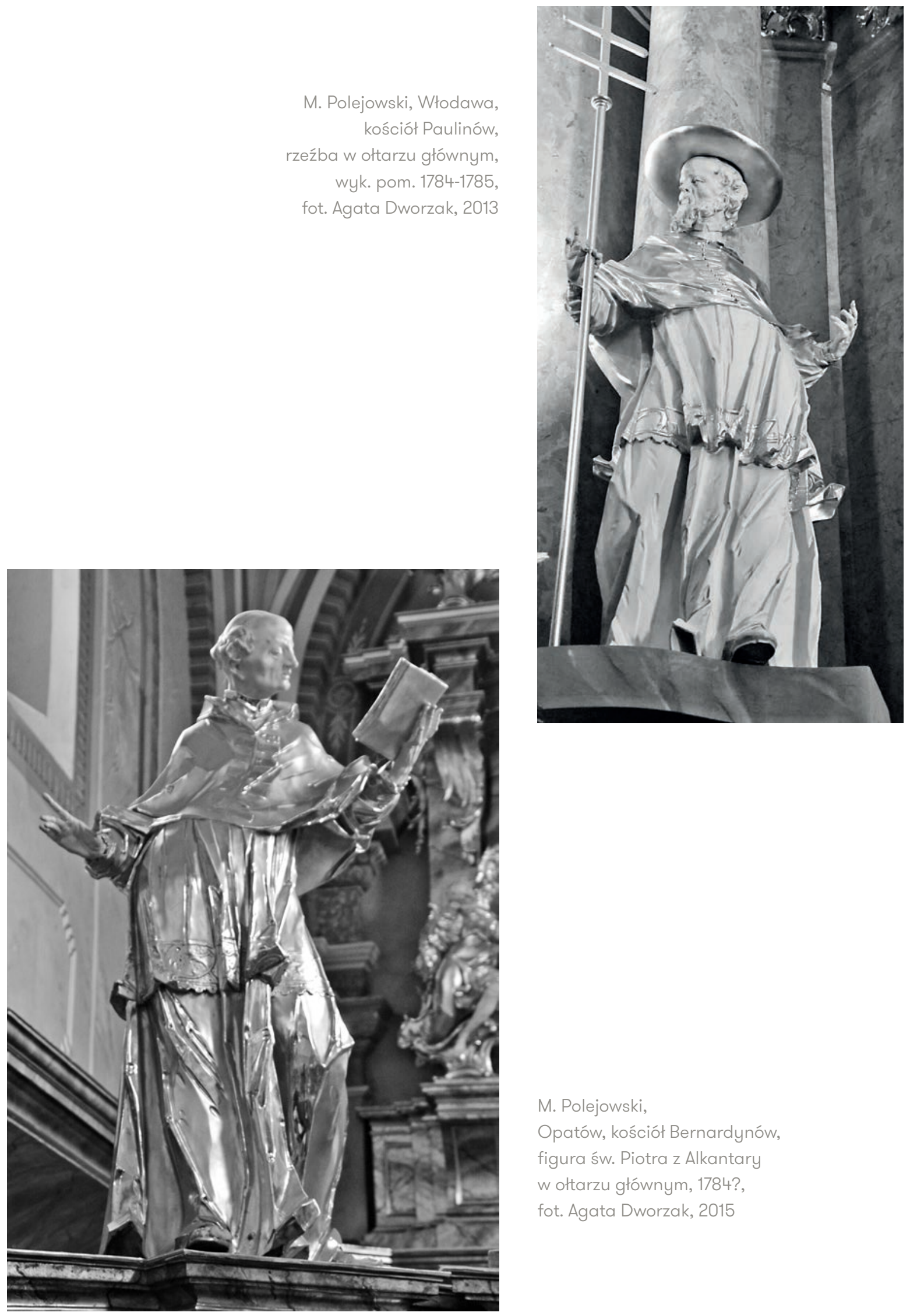

M. Polejowski,

Opatów, kościół Bernardynów,

figura św. Piotra z Alkantary

w ołtarzu głównym, 1784?,

fot. Agata Dworzak, 2015 


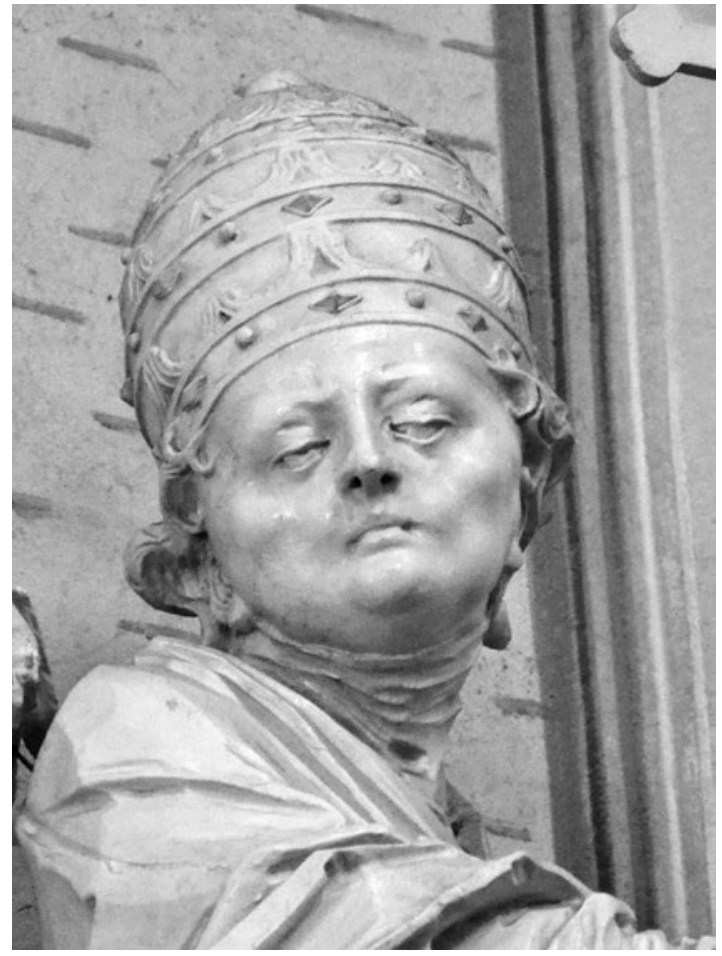

M. Polejowski, Włodawa, kościół Paulinów, rzeźba św. Grzegorza w nawie, wyk. pom. 1784-1785, fot. Agata Dworzak, 2013.

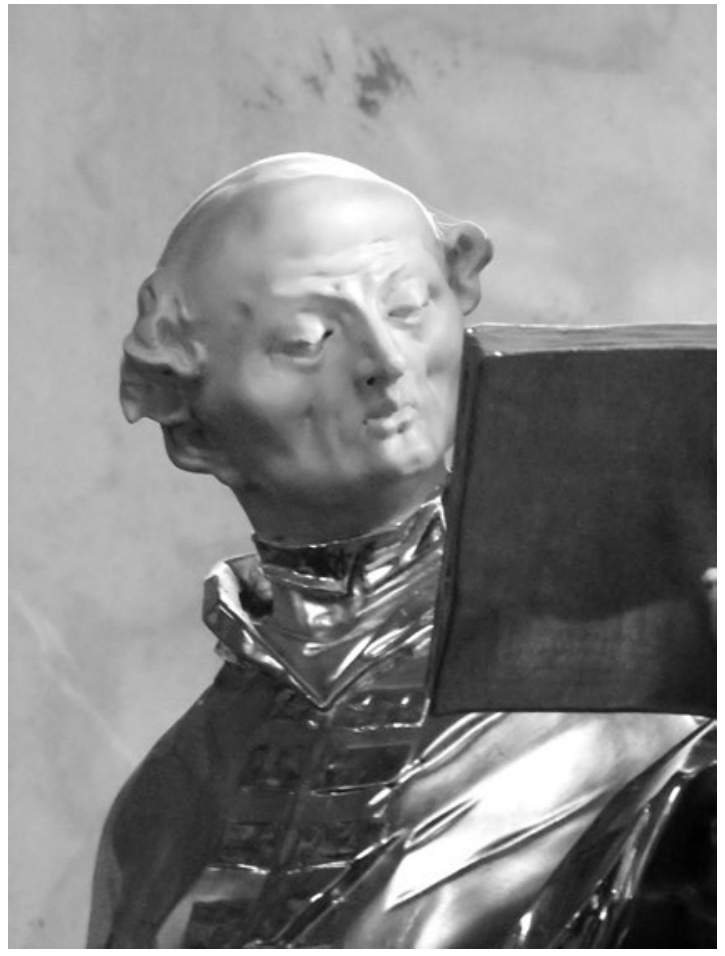

M. Polejowski, Opatów, kościół Bernardynów, figura św. Piotra z Alkantary w ołtarzu głównym, 1784?, fot. Agata Dworzak, 2015;

archiwalnie dzieł Macieja Polejowskiego, obok prac w Nawarii (ok. 1765 roku) i figur z ołtarza katedralnego we Lwowie (1765-1770). Jednakże zestawienie ze sobą rzeźb $\mathrm{z}$ tych realizacji ujawnia daleko idące różnice w kształtowaniu kompozycji i fizjonomii postaci. Widoczne jest to przy porównaniu figur Boga Ojca ze zwieńczenia ołtarza z Nawarii ze św. Bonawenturą z Opatowa. Figury z Nawarii ujawniają bowiem pod jak dużym wpływem stylistyki Pinsla pozostawał Maciej Polejowski na początku działalności w latach 60. XVIII wieku. Już one zawierają jednak charakterystyczne cechy, które będą w późniejszym czasie świadczyć o osobistym stylu rzeźbiarza. Chodzi o pogłębiający się kontrapost i eleganckie skręcenie sylwetek, nieco wydłużone proporcje postaci z masywnymi udami. Figury z Nawarii otrzymały jeszcze „odziedziczoną" po dziełach Pinsla bardzo wyrazistą fizjonomię, z szerokim, płasko ściętym nosem, połączonym z mocno wydobytymi łukami brwiowymi oraz głęboko osadzonymi oczodołami z pojedynczo rzeźbionymi rzęsami. Figura anioła ze zwieńczenia, mimo mniejszego ładunku emocjonalnego, zdradza podobne, wyraziste cechy.

Dodając do tego porównania figury z katedry lwowskiej, skądinąd o nie najwyższej klasie artystycznej, otrzymamy obraz wyraźnej ewolucji stylu Macieja Polejowskiego, który na przełomie lat 60. i 70. krystalizował swój język artystyczny. Ciężko zatem zgodzić się z propozycją, aby rzeźby z Nawarii i z Opatowa powstały w tym 
samym roku. Wiadomo, że bezpośrednio po zakończeniu prac w Sandomierzu Polejowski przeniósł swój warsztat do Zasławia, pozostając tam do końca 1774 roku. W latach 1774-1776 ponownie pracował w katedrze lwowskiej, jednocześnie wykonując zlecenie dla dominikanów lwowskich. Za reprezentatywny przykład jego twórczości w tym okresie można uznać choćby figurę św. Dominika czy kanonika regularnego z Vallis Viridis spod tamburu kościoła oo. Dominikanów. Zestawienie figur opatowskich z pracami Polejowskiego we Włodawie (datowanymi pomiędzy latem 1784 a latem 1785 roku $^{22}$ ) ukazuje podobieństwa w traktowaniu kompozycji postaci oraz fizjonomii. Można wskazać podobnie kształtowane nosy, lekko opadnięte powieki czy kształt głowy z wysklepionym czołem i półokrągłą brodą.

Te spostrzeżenia sytuują ołtarz opatowski w dojrzałej fazie twórczości Polejowskiego, raczej właśnie w okolicy lat 80 . Być może wystawienie struktury ołtarza należałoby łączyć z 1784 rokiem, kiedy całe wnętrze kościoła otrzymało nową, iluzjonistyczną polichromię o tematyce maryjnejej3. Wybór ikonografii wiązał się z wezwaniem kościoła oraz rosnącym, acz całkowicie lokalnym, kultem wizerunku Matki Boskiej Niepokalanej, a z czasem także i drugiego obrazu - Matki Boskiej Pocieszenia. Pierwszemu z nich przypisywano ochronę przed pożarem, który w 1751 roku strawił ponad 300 domów w mieście, omijając kościół. Drugi wsławił się licznymi cudami, których świadectwem było blisko 60 wotów opisanych inwentarzem z połowy XVIII wieku ${ }^{24}$. Rozbieżność dotychczasowego datowania wynika z braku późniejszych źródeł i mechanicznego połączenia przez Betleja ołtarza konsekrowanego w 1765 roku z osobą Polejowskiego. Istniejący wówczas ołtarz musiał być po prostu wcześniejszą strukturą.

Pomijając kwestie datowania retabulum opatowskiego, bezsprzecznym pozostaje fakt zastosowania w strukturach zasławskiej i opatowskiej charakterystycznych zabiegów kompozycyjno-optycznych. Odnaleźć można je także, w najprawdopo-dobniej ostatnim dziele Polejowskiego, ołtarzu głównym wielkiej cerkwi poczajowskiej, wystawionym pomiędzy rokiem 1790 a $1791^{25}$. Struktura została zaprojektowana kulisowo, na dwóch planach. Warto wskazać na wspólny z Zasławiem i Opatowem schemat kompozycyjny tylnego retabulum, wysmukłego, bogato dekorowanego rocaillem, z postrzępionym zwieńczeniem, flankowanego grupami

\footnotetext{
22 Dotychczasowe datowanie pomiędzy rokiem 1783 a 1786 zawęziła ostatnio Magdalena Ludera, na podstawie inwentarzy kościelnych oraz analizy malowideł we wnętrzu kościoła, zob. LUDERA 2016, s. 153. 
TECHNE

T E X N H

SERIA NOWA
218

M. Polejowski, Zasław,

kościół Bernardynów,

ołtarz gł. wyk. 1774, fot. 1913,

wg. TOKARZEWSKI 1913

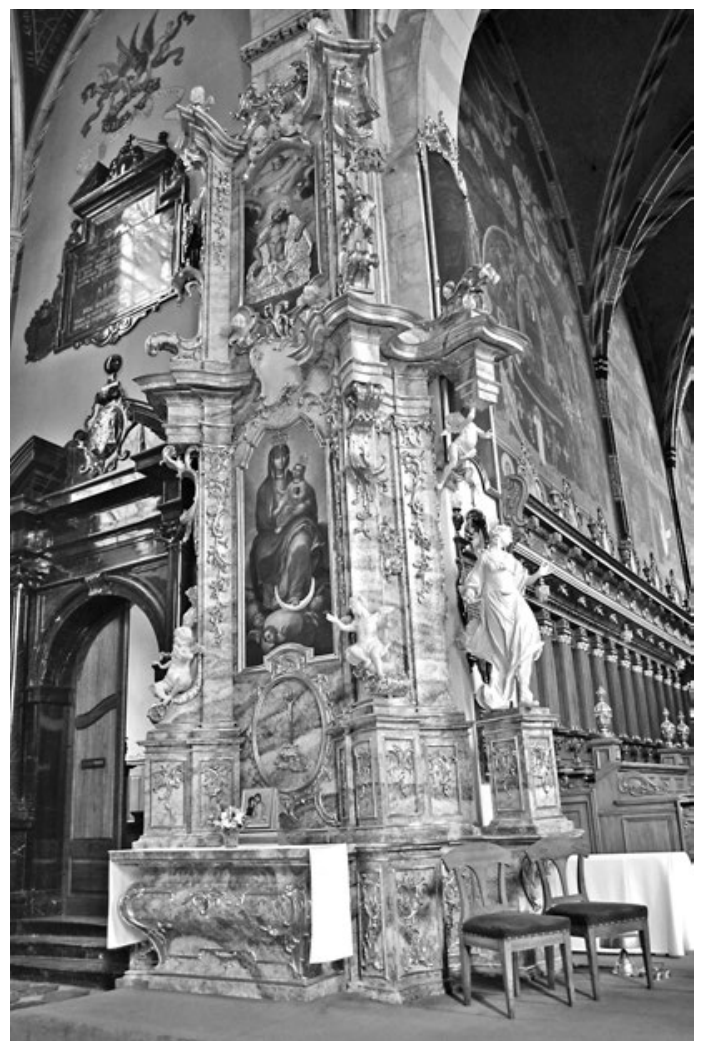

M. Polejowski, Poczajów,

Cerkiew p.w. Wniebowzięcia

Najświętszej Marii Panny, ołtarz główny, wyk. pom. 1790-1791, rycina nieznanego autora w zbiorach Muzeum Narodowego w Kijowie, fot. Agata Dworzak, 2016

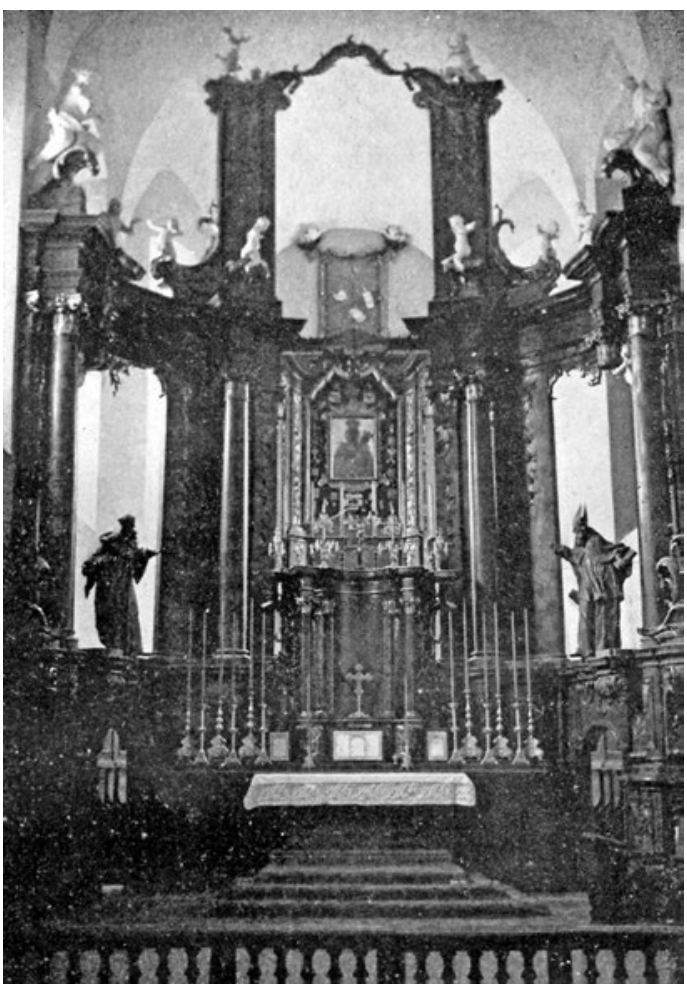

M. Polejowski, Sandomierz,

katedra, ołtarz Matki Boskiej,

wyk. 1771-1773,

fot. Agata Dworzak, 2014

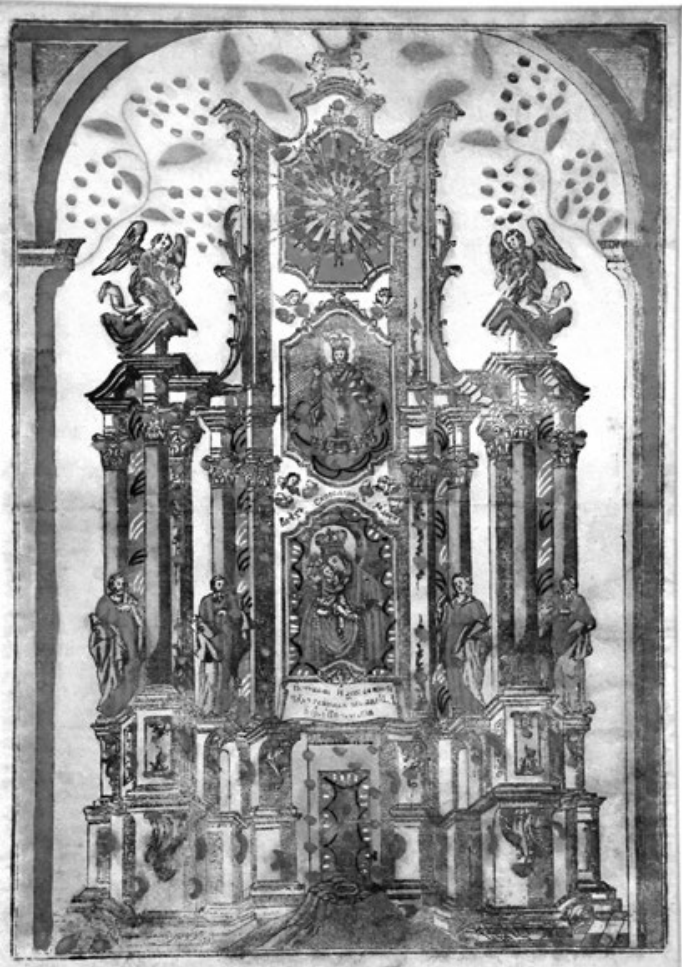


niemal wolnostojących kolumn z aniołami na przyczółkach. Mamy tu do czynienia z połączeniem szeroko stosowanej przez Macieja Polejowskiego wydłużonej, lekkiej, dwukondygnacyjnej i ornamentalnej struktury ołtarza, z mocnym, plastycznym akcentem $\mathrm{z}$ ruchem dośrodkowym, w postaci dostawionych na kilku płaszczyznach kolumn, ponownie zaczerpniętych z Horodenki.

Jak widać w twórczości braci Polejowskich obecne są dwa nurty w projektowaniu małej architektury, które na zasadzie pars pro toto można także rozważać jako dwa główne kierunki w lwowskiej sztuce drugiej połowy XVIII stulecia. Nastawy, oddziałujące monumentalnością, bogactwem dekoracji i zwielokrotnieniem artykulacji, wprost kontynuujące meretynowskie wzorce z Horodenki, reprezentowane przez Piotra Polejowskiego, będą inspirowały także innych mistrzów, jak choćby Michała Filewicza w jego realizacji w Chełmie ${ }^{26}$. W świetle nowych informacji archiwalnych ta zależność obu artystów nie dziwi, bowiem Filewicz był czeladnikiem Piotra Polejowskiego ${ }^{27}$. Weryfikuje to wysuwane w literaturze supozycje, jakoby Michał Filewicz miał się uczyć u Pinsla ${ }^{28}$.

Podobny schemat prezentują także retabula z kościoła i cerkwi buczackich, ołtarze boczne u karmelitów przemyskich, czy też ołtarz główny w Kąkolnikach i część wyposażenia lwowskiego kościoła Marii Magdaleny. Ten nurt należy skontrastować z „lekkimi”, dwuplanowymi, ażurowymi kompozycjami Macieja Polejowskiego, umiejętnie wykorzystującymi efekty świetlne, grę z widzem, poprzez kulisowość i nakładanie się planów w celu wyeksponowania cudownego wizerunku. Wydaje się, że mogły one wywrzeć wpływ na ołtarz główny w Przemyślanach (całe wyposażenie ogólnie datowane jest na lata 80 . XVIII wieku ${ }^{29}$ ). Choć nowe źródła ujawniły, że dwa ołtarze boczne powstały w 1766 roku, a ich autorem był Michał Filewicz ${ }^{30}$. Należałoby więc zastanowić się nad zmianą datowania tego zespołu i jego ponowną analizą. Jak wiadomo twórczość Macieja otworzyła także nowy rozdział w dziejach lwowskiej rzeźby na terenie Sandomierszczyzny, gdzie masowo kopiowano jego rozwiązania.

KRASNY 2005a, s. 177.

Zagadnienie to szczegółowo rozważam w rozprawie doktorskiej sygnalizowanej w przypisie 1.

Por.: КОЗЯР-ФЕДОМОВ 2012a, s. 64; КОZYR-FEDOTOV 2012b, s. 70; KOZYR-FEDOTOW 2012c,

s. 113.

ZAUCHA 2003, s. 228.

Zagadnienie to szczegółowo rozważam w rozprawie doktorskiej sygnalizowanej w przypisie 1. 


\section{Bibliografia:}

\section{Źródła:}

- APPB-Kr., M-28 - Archiwum Polskiej Prowincji Bernardynów w Krakowie, sygn. M-28, Inwentarz zakrystii klasztorów Prowincji Małopolskiej Zakonu Braci Mniejszych Bernardynów, ok. 1750, s. 13-15, Conventus Opatoviensis S. Mariae Assumptae.

- BCz.-Kr., 3365 - Biblioteka XX. Czartoryskich w Krakowie, sygn. 3365, Descriptio brevis Ecclesiae loci Opatov.

\section{Opracowania:}

- BARANOWSKI 2003 - Andrzej Józef Baranowski, Koronacje wizerunków maryjnych w czasach baroku. Zjawisko kulturowe i artystyczne, Warszawa 2003.

- BETLEJ 1995 - Andrzej Betlej, Kościót oo. Bernardynów w Zasławiu. Źródła archiwalne do dziejów wystroju późnobarokowego, „Biuletyn Historii Sztuki”, t. 57, 1995, s. 353-363.

- BETLEJ 2003 - Andrzej Betlej, Polejowski Jan, Maciej, Piotr, [w:] Słownik Artystów Polskich, t. 7, 2003, s. 373-380.

- BETLEJ 2006 - Andrzej Betlej, Inspiracje graficzne dla „małej architektury” na ziemiach ruskich Korony - uwagi na marginesie projektu ikonostasu katedry św. Jura we Lwowie, [w:] Praxis atque theoria. Studia ofiarowane Profesorowi Adamowi Małkiewiczowi, red. Jan. Ostrowski, Piotr Krasny, Andrzej Betlej, Kraków 2006, s. 55-76.

- BRZEZINA 2007 - Katarzyna Brzezina, Na skrzyżowaniu dróg artystycznych, czyli o osiemnastowiecznym wyposażeniu rzeźbiarskim kościołów Opatowa, [w:] Barok i barokizacja. Materiały sesji oddziału Krakowskiego Stowarzyszenia Historyków Sztuki, Kraków 3-4 XII 2004, red. Katarzyna Brzezina, Joanna Wolańska, Kraków 2007, s. 181-189.

- DUTKIEWICZ 1939 - Józef Edward Dutkiewicz, Fabryka cerkwi Wniebowzięcia N.M.P. w Poczajowie, „Dawna Sztuka", t. 2, 1935, s. 131-162.

- DWORZAK 2013 - Agata Dworzak, „Nie może mi Wielebny Monaster zadać, aby robota niebyła doskonała”. Kilka uwag na temat sporu Macieja Polejowskiego z bazylianami poczajowskimi, „Biuletyn Historii Sztuki”, t. 75, 2013, s. 101-114.

- DWORZAK 2014 - Agata Dworzak, New Aspects of the Idea of Bel Composto in Artistic Realizations of Piotr and MaciejPolejowskis, the Artistic Family from Lviv (1761-1786), [w:] Cultural Transfer. Uměleckávýměnameziltálií a středníEvropou, red. Martin Zlatohlávek, Praha 2014, pp. 129-134.

- DWORZAK 20016a - Anna Dworzak, Zapomniany kult wizerunku Matki Boskiej w kościele bernardyńskim w Rzeszowie, [w:] Sanktuarium Matki Bożej Rzeszowskiej 1513-2013, red. Aleksander Krzystof Sitnik OFM, Wiktor Piotr Tokarski OFM, Kalwaria Zebrzydowska 2016, s. 403-405.

- DWORZAK 2016b - Anna Dworzak, FABRICA ECCLESIAE SANDOMIRIENSIS. Dzieje modernizacji wnętrza kolegiaty sandomierskiej w XVIII wieku w świetle źródeł archiwalnych, Kraków 2016.

- FRAZIK 2004 - Józef Tomasz Frazik, Budowniczowie i artyści na usługach franciszkanów przemyskich od XV do XVIII wieku, [w:] Idem, Sztuka Przemyśla i Ziemi Przemyskiej. Zbiór studiów, red. Maria Dłutek, Jerzy Kowalczyk, Przemyśl-Warszawa 2004, s. 117-141 [przedruk artykułu: Budowniczowie i artyści na usługach franciszkanów przemyskich od XV-XVIII wieku na tle kościoła i jego wyposażenia, „Biuletyn Historii Sztuki”, t. 37, 1975, s. 312-334].

- FRIDRICH - Alojzy Fridrich, Historye cudownych obrazów Najświętszej Maryi Panny w Polsce, t. 2, Kraków 1904. 
- GĘBAROWICZ 1986 - Mieczysław Gębarowicz, Prolegomena do dziejów lwowskiej rzeźby rokokowej, „Artium Quaestiones”, t. 3, 1986, s. 5-46.

- GRUDZIŃSKI 1985 - Kajetan Grudziński OFM, Opatów, [w:] Klasztory bernardyńskie w Polsce w jej granicach historycznych, red. Hieronm Eugeniusz Wyczawski OFM, Kalwaria Zebrzydowska 1985, s. 239-244.

- HORNUNG 1976 - Zbigniew Hornung, Majster Pinzelsnycerz. Karta z dziejów lwowskiej rzeźby rokokowej, Wrocław 1976.

- KOWALCZYK 1959 - Jerzy Kowalczyk, Prace rzeźbiarskie Macieja Polejowskiego w Sandomierskim i na Lubelszczyźnie, „Sprawozdania Towarzystwa Naukowego w Toruniu”, t. 2, 1959, s. 123-127.

- KOWALCZYK 1970 - Jerzy Kowalczyk, Dzieła Macieja Polejowskiego w Ziemi Sandomierskiej, „Rocznik Muzeum Świętokrzyskiego", t. 6, 1970, s. 187-234.

- КОЗЯР-ФЕДОМОВ 2012а, - ОксанаКозяр-Федомов, Усправіаворстваскулптурнегоансамблюиеркв ив Бучачі, „ЛьвівськаНаціональнаГалереяМистецтвДослідження і Мвтеріали. Науковий”, Львів 2012, c. 58-69.

- KOZYR-FEDOTOV 2012b - Oksana Kozyr-Fedotov, Pinsel et sonécole, catalogued'exposition Johann Georg Pinsel unsculpteurbaroque en Ukraine au XVIII siècle, dir. Jan Ostrowski, G. Scherf, Paris 2012, p. 64-73.

- KOZYR-FEDOTOW 2012c - Oksana Kozyr-Fedotow, Michał Filewicz, rzeźbiarz lwowskiego rokoka, [w:] Splendor i fantazja. Studia nad rzeźbą rokokowa w dawnej Rzeczypospolitej i na Śląsku, red. Paweł Migasiweicz, Warszawa 2012, s. 109-136.

- KRASNY/SITO 2003 - Piotr Krasny, Jakub Sito, „Pan Piotr Polejowski snycerz lwowski” i jego dzieła w kościele Franciszkanów w Przemyślu, [w:] Sztuka kresów wschodnich, t. 5, red. Andrzej Betlej, Piotr Krasny, Kraków 2003, s. 175-202.

- KRASNY 2005a - Piotr Krasny, Lwowskie środowisko artystyczne wobec idei symbiozy sztuk w wystroju i wyposażeniu wnętrz sakralnych (1730-1780), „Rocznik Historii Sztuki”, t. 30, 2005, s. 147-190.

- KRASNY 2005b - Piotr Krasny, Kościót i klasztor Dominikanów w Podkamieniu, [w:] Materialy do dziejów sztuki sakralnej, red. Jan. Ostrowski, cz. I, Kościoly i klasztory rzymskokatolickie dawnego województwa ruskiego, t. 13, Kraków 2005, s. 123-192.

- NOWAKOWSKI 1902 - Edward Nowakowski, O cudownych obrazach w Polsce Przenajświętszej Matki Bożej wiadomości historyczne, bibliograficzne i ikonograficzne przez X. Wacława z Sulgostowa, Kraków 1902.

- ZAUCHA 2003 - Tomasz Zaucha, Kościót parafialny p.w. ŚŚ. Piotra i Pawła i dawny klasztor OO. Dominikanów Obserwantów w Przemyślanach, [w:] Materiały do dziejów sztuki sakralnej, red. Jan Ostrowski, cz. I, Kościoły i klasztory rzymskokatolickie dawnego województwa ruskiego, t. 11, Kraków 2003, s. 211-237. 


\section{Altars with Venerated Images in the Artistic Output of the Polejowski Brothers}

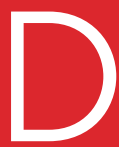

espite the fundamental work by Andrzej Józef Baranowski which discusses the veneration of holy Marian images in the former Polish Republic, the influence of holy paintings on the artistic initiative still remains underrated, primarily in terms of the furnishing of sanctuary churches. It must not be forgotten that the celebrations with these images were the reason behind numerous interior modernisations, the replacements of furnishings and fittings - mainly altars - and the translocations of paintings, veneration and anniversary celebrations. In the Ruthenian Voivodeship, these actions resulted in a series of most superb artistic realisations in the $18^{\text {th }}$ century Polish Republic, such asthe central altars in the parish church in Hodowica, the Franciscan church in Przemyśl, the Dominican church in Podkamien, or the Latin Cathedral in Lviv. Since the majority of these are directly or indirectly linked to brothers Piotr and Maciej Polejowski, it is worth making an attempt to analyse the schemes and compositional solutions they had worked out. On the one hand, there will be structures designed by Piotr Polejowski, which expand and 'distend' church presbyteries, creating a multiplied frame for holy paintings (the altar of the Franciscan church in Przemyśl and in the Latin Cathedral in Lviv) accompanied by elaborate and complex iconographic programmes. The second trend entails reredoses designed by Maciej Polejowski, openwork, two-panel screens and high pedestals with gates upfront, complemented with free-standing pillars and sculptures in the clearances, behind which the very reredos with the holy painting can be seen. This design was implemented in the Bernardine screens in Opatów and Zaslav. Thus, we face two trends in designing altars by the Polejowski Brothers, and sensu largo within the Lviv art in the second half of the $18^{\text {th }}$ century. Piotr Polejowski's reredoses - with their impacting monumentality, abundance of decorations and multiplicity of articulations, directly continuing Meretynean patterns from Horodenka- are contrasted with Maciej Polejowski's 'light', two-panel, openwork compositions that so skilfully applied light effects and played with the audience through their backstage-like design and overlapping of sets aimed at exposing the holy image. 